\title{
Larval and Juvenile Fishes Occurring in Surf Zones of Western Japan
}

\author{
Tetsushi Senta \\ Nagasaki University Nomo Fisheries Station \\ Nomozaki-cho, Nagasaki-ken 851-05, Japan \\ IZUMI KINOSHITA \\ Nishinihon Technological Institute \\ 9-30 Wakamatsu-cho, Kochi 780, Japan
}

\begin{abstract}
Fish larvae and juveniles were collected in the waters of wading depth along sandy beaches of western Japan with a $0.7-\mathrm{mm}$-mesh, 1.3- by 5-m seine. Presence of Chanos chanos, Salangichthys microdon, Plecoglossus altivelis, Allanetta bleekeri, Gerres oyena, Sparus sarba, Acanthopagrus schlegeli, A. latus, and Lateolabrax latus and absence of Engraulis japonica, Gonorhynchus abbreviatus, Upeneus bensasi, and Macrorhamphosus scolopax distinguished the larval ichthyofauna of surf zones from those in other known biotopes of fish nursery. The surf ichthyofauna was usually more diverse in spring and summer than in autumn and winter. Monthly total catches of individuals fluctuated greatly according to the abundances of a few influential species such as Clupanodon punctatus in spring and Plecoglossus altivelis in autumn to winter. Most larval fishes seemed to inhabit surf zones only during daytime. An influence of tidal phases on occurrence of larval fishes was not apparent. Categories of pelagic and demersal components were suggested for surf zone ichthyofauna.
\end{abstract}

Much work has been done on the ichthyofauna in surf zones of sandy beaches of the United States, Europe, and South Africa (McLachlan 1983). Nets used in such studies were largemeshed and designed to be towed along the sea bed. Consequently, larval and juvenile fishes as small as those commonly occurring in plankton net samples have been seldom reported from surf zones.

Our studies of the surf zone ichthyofauna in Japan began in 1977. At first, we concentrated on distributions of young milkfish Chanos chanos, a species of aquacultural importance in southeast Asia since the 14th century (Schuster 1952), but whose larvae had been collected only rarely from Japanese waters. Lately, our assessments have broadened to include larval and juvenile fishes of other species in the surf zone. In this paper, we present some general results of our surveys, which show the ichthyoplankton assemblages of the surf zone to differ from those of other biotopes, and to vary over diel and seasonal periods.

\section{Methods}

Our first surveys for young milkfish covered sandy beaches in 55 places from Okinawa to $\mathrm{Kii}$
Peninsula during June-September 1977, 1978, and 1979. Most of these places were visited only once or twice, except for Tanegashima Island where we repeated collections at two beaches on 44 days and 25 days, respectively, in 1978 to study the seasonal occurrence of milkfish. Most fish specimens other than milkfish were discarded on the spot.

Since July 1980, all fish specimens collected have been brought back to the laboratory, and collections at various places have been made (Fig. 1). Year-round collections are being carried out at beaches of four regions on the west coast of Kyushu and at three beaches facing Tosa Bay, Shikoku.

Our seines are similar to those used to collect young milkfish in the Philippines, locally known as sagyap or sarap (Kumagai et al. 1980). The one used at most sites is an unweighted, 1.3- by $5-\mathrm{m}$ piece of polyester netting, $0.7 \mathrm{~mm}$ in mesh width, $0.2 \mathrm{~mm}$ in strand diameter, and strengthened along the edges with 6-mm-diameter nylon rope. Each end of the net is attached to a stick handle. The net used along Tosa Bay is 1 by 4 $m$ in size with a mesh width of $1 \mathrm{~mm}$ and a shallow conical bag at its center.

The stretched net is pulled by two persons along 


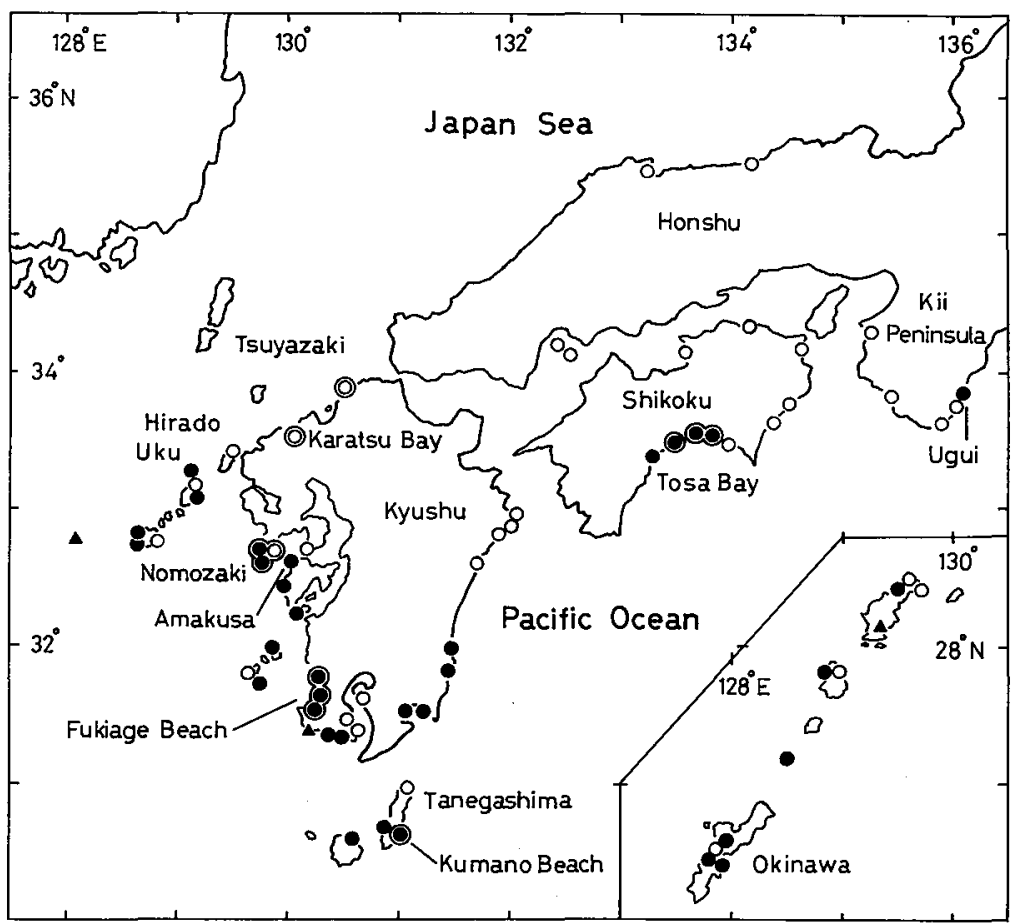

FIGURE 1.-Map of southwestern Japan showing beaches where ichthyoplankton was collected in surf zones. Beaches represented by double circles have been continuously surveyed; others were visited only once or twice. Solid dots indicate the occurrence of larval milkfish. Three solid triangles show places where a single milkfish larva each was caught before 1977. Three double circles on Tosa Bay from the west to east show Usa, Tanesaki, and Tei beaches.

$50 \mathrm{~m}$ of beach in water within wadable depths. Such depths represent the inner portion of the surf zone. The lower margin of the net is kept well above the sea bed and at least the upper onethird of the net is kept in the air. We repeated the hauls four or five times for one collection. Specimens were preserved in 5 to $10 \%$ formalin and sorted and measured in the laboratory.

\section{Results and Discussion Larval Milkfish}

Before 1977, only three milkfish larvae, 14.0 to $14.7 \mathrm{~mm}$ TL (total length), had been reported (triangles in Fig. 1: Yoshida 1932, 1933; Senta 1956). In spite of nation-wide surveys of pelagic fish eggs and larvae with plankton samplers in Japan that started in 1952 (Uchida and Dotsu 1958) and are still continuing, these are the only three known cases of young milkfish being caught outside the surf zone.

In contrast, we have captured young milkfish in the surf zone throughout our study area, which extends northward to Kii Peninsula (Fig. 1). They were especially abundant at Tanegashima and southward. At Kumano beach of Tanegashima, the daily average catch reached 79 milkfish per haul on July 27, 1978 (Senta et al. 1980).

We consider larval milkfish one of the features that distinguish the surf zones of southern Japan from other biotopes.

\section{Dominant Species}

We made 24 seine hauls in July 1980 and 52 in August 1981 at Kumano beach, Tanegashima, and collected 773 fish belonging to 18 species of 16 families. Stolephorus indicus accounted for $32.0 \%$, Chanos chanos for $16.5 \%$, Atherinidae spp. for $15.5 \%$, and Gerres oyena for $14.5 \%$ of the total number.

During July 1980 to January 1982, we made 568 hauls at beaches on the west coast of Kyushu (double circles in Fig. 1). Collections were more intensive in the Nomozaki region than elsewhere, and in May to November than in other months. We caught 7,091 fish of 64 species belonging to 52 families. The 10 top-ranking species 
TABLE 1.-Comparison of dominant species of larval and juvenile fishes collected from various biotopes on and off the west coast of Kyushu. Blank spaces for the percentage mean the species was not caught; + indicates less than $0.05 \%$.

\begin{tabular}{|c|c|c|c|c|c|c|c|c|}
\hline \multirow[b]{2}{*}{ Species } & \multicolumn{2}{|c|}{$\begin{array}{l}\text { Surf zones; } \\
\text { small seine } \\
(N=7,091)\end{array}$} & \multicolumn{2}{|c|}{$\begin{array}{l}\text { Zostera belt; } \\
\text { beam trawl } \\
(N=17,396)\end{array}$} & \multicolumn{2}{|c|}{$\begin{array}{l}\text { Drifting seaweeds; } \\
\text { scoop net } \\
(N=14,021)\end{array}$} & \multicolumn{2}{|c|}{$\begin{array}{l}\text { Coastal waters; } \\
\text { plankton sampler } \mathrm{d} \\
(N=93,125)\end{array}$} \\
\hline & Rank & $\%$ & Rank & $\%$ & Rank & $\%$ & Rank & $\%$ \\
\hline Gerres oyena & 1 & 29.7 & 7 & 2.9 & & & & + \\
\hline Allanetta bleekeri & 2 & 20.2 & & & & & & + \\
\hline Mugilidae spp. & 3 & 8.5 & & & 17 & 0.8 & & + \\
\hline Salangichthys microdon & 4 & 6.6 & & & & & & \\
\hline Conidens laticephalus & 5 & 6.5 & & & & & & \\
\hline Clupanodon punctatus & 6 & 5.9 & & & & & & \\
\hline Herklotsichthys zunasi & 7 & 3.8 & & & & & & \\
\hline Takifugu niphobles & 8 & 3.1 & & + & & & & + \\
\hline Sparus sarba & 9 & 2.9 & & & & & & \\
\hline Gobiidae spp. & 10 & 2.7 & 4 & 8.7 & & & & + \\
\hline Plotosus anguillaris & & + & 1 & 29.5 & & & & \\
\hline Rudarius ercodes & 18 & 0.7 & 2 & 24.9 & 1 & 18.5 & 8 & 0.4 \\
\hline Pseudoblennius spp. & 12 & 1.9 & 3 & 9.9 & & & & \\
\hline Hyposytes rubripinnis & & & 5 & 6.5 & & & & \\
\hline Sebastes inermis & & & 11 & 1.4 & 2 & 15.6 & & + \\
\hline Girella punctata & 13 & 1.8 & & & 3 & 15.5 & 6 & 0.5 \\
\hline Stephanolepis cirrhifer & & & $?$ & 0.2 & 4 & 7.8 & 13 & 0.2 \\
\hline Urocampus rikuzenitus & & & & & 5 & 6.5 & & \\
\hline Engraulis japonica & 20 & 0.5 & & & & & 1 & 88.0 \\
\hline Sardinops melanostictus & & + & & & & & 2 & 2.4 \\
\hline Upeneus bensasi & & & & & & & 3 & 1.1 \\
\hline Sebastiscus marmoratus & & & & & & & 4 & 0.7 \\
\hline Macrorhamphosus scolopax & & & & & & & 5 & 0.6 \\
\hline
\end{tabular}

\footnotetext{
a July 1980-January 1982 (present study).

d May 1953-March 1957 (Senta 1964).

b November 1958-December 1959 (Kikuchi 1966).

c April 1958-March 1959 (Shojima and Ueki 1964).

e Impossible to know from the data given.
}

TABLE 2.-Comparison of dominant species of larval and juvenile fishes collected in surf zones and neighboring shallow waters of Tosa Bay and coastal waters off the south coast of Shikoku and the east coast of Kyushu. Blank spaces for the percentage mean the species was not caught; + indicates less than $0.05 \%$.

\begin{tabular}{|c|c|c|c|c|c|c|}
\hline \multirow[b]{2}{*}{ Species } & \multicolumn{2}{|c|}{$\begin{array}{c}\text { Surf zones; } \\
\text { small seine }^{\mathrm{a}} \\
(N=89,296)\end{array}$} & \multicolumn{2}{|c|}{$\begin{array}{l}\text { Shallow waters; } \\
\text { minnow bag net } \\
(N=239,345)\end{array}$} & \multicolumn{2}{|c|}{$\begin{array}{l}\text { Coastal waters; } \\
\text { plankton samplerc } \\
(N=217,132)\end{array}$} \\
\hline & Rank & $\%$ & Rank & $\%$ & Rank & $\%$ \\
\hline Clupanodon punctatus & 1 & 43.0 & & & & + \\
\hline Plecoglossus altivelis & 2 & 36.7 & 7 & 0.6 & & + \\
\hline Crenimugil crenilabis & 3 & 7.4 & & & & $+?^{d}$ \\
\hline Takifugu niphobles & 4 & 3.9 & & & & 0.1 ? \\
\hline Gerres oyena & 5 & 2.5 & & + & & + \\
\hline Acanthopagrus latus & 6 & 2.0 & & + & & \\
\hline Gobiidae spp. & 7 & 1.1 & 4 & 2.5 & & + \\
\hline Acanthopagrus schlegeli & 8 & 0.7 & & & & 0.1 \\
\hline Sparus sarba & 9 & 0.4 & & & & \\
\hline Sardinops melanostictus & 10 & 0.4 & 2 & 22.6 & 6 & 1.3 \\
\hline Engraulis japonica & & + & 1 & 56.8 & 1 & 75.0 \\
\hline Etrumeus teres & & + & 3 & 13.2 & & 0.2 \\
\hline Saurida sp. & & & 5 & 1.5 & & 0.1 ? \\
\hline Gonorynchus abbreviatus & & & & & 2 & 9.5 \\
\hline Upeneus spp. & & + & & & 3 & 2.7 \\
\hline Cololabis saira & & & & & 4 & 1.4 \\
\hline Macrorhamphosus scolopax & . & & & & 5 & 1.3 \\
\hline
\end{tabular}

a May 1981-May 1982 (present study).

b April 1979-March 1982 (Kochisuishi 1981, 1982, 1983).

c April 1966-March 1968 (Matsuda 1969).

Identification to the family level. 


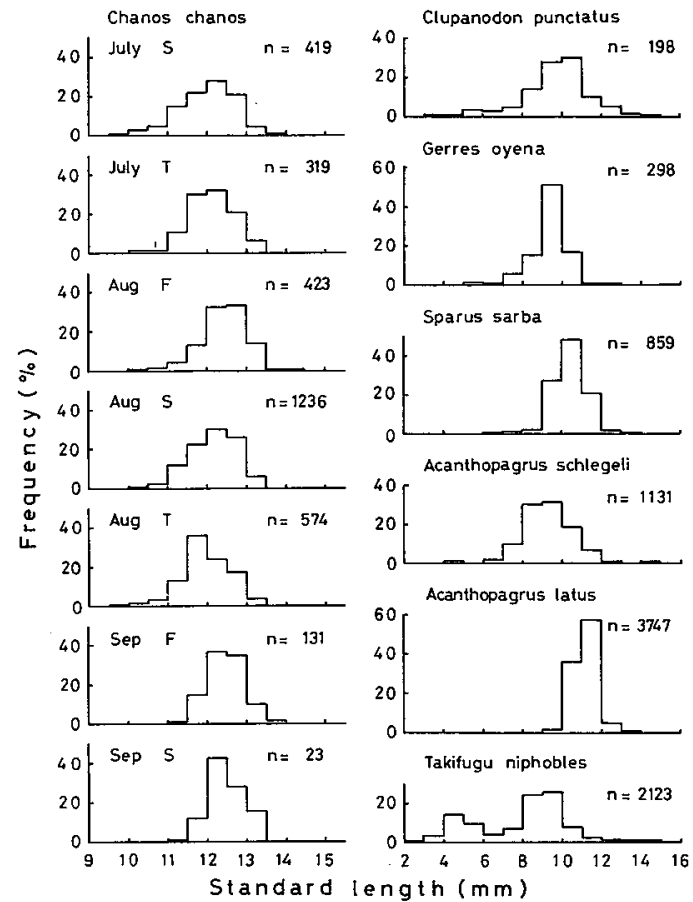

FIGURE 2.-Length frequencies of selected fishes showing a narrow range of body length while inhabiting surf zones of southern Japan. $\boldsymbol{F}, \boldsymbol{S}, \boldsymbol{T}$ after the names of month denote the first, second, and third 10-d periods of the month, respectively.

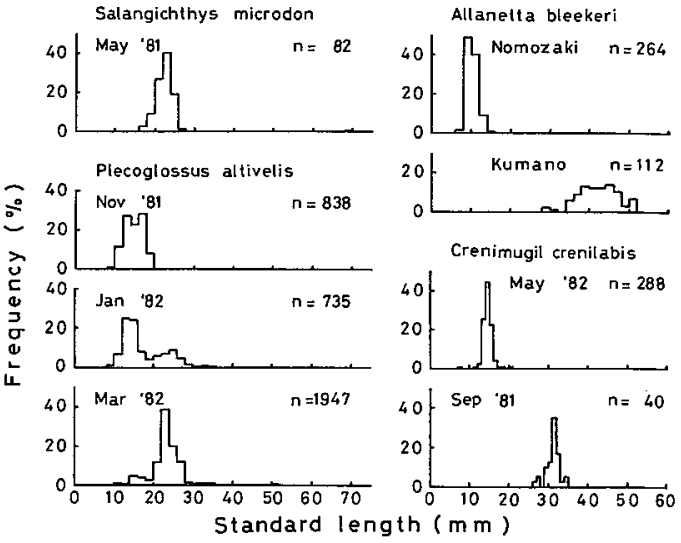

FIGURE 3.-Length frequencies of fishes showing a wide range of body length in Japanese surf zones.

of the surf zone were poor or unrepresented in other nearby biotopes, except for gobiids and Gerres oyena which were rather abundant in Zostera belts (Table 1). None of the five topranking fishes in the other biotopes ranked above 10 in the surf zones. The difference in ichthyofauna between surf zones and offshore plankton is particularly striking.

Semimonthly collections at three beaches of Tosa Bay from May 1981 to May 1982 yielded

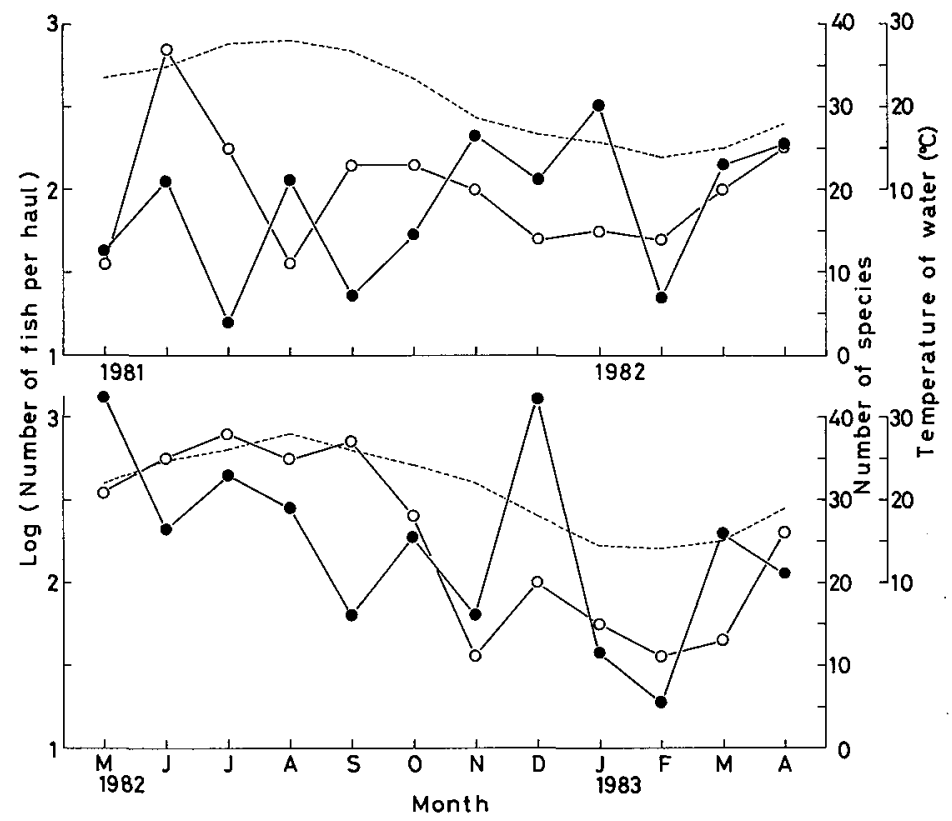

FIGURE 4.-Monthly fluctuations in total number of species (open dots) and number of fish per haul (solid dots) collected at three beaches on Tosa Bay during May 1981 to April 1983. Mean water temperature is shown by a broken line. 


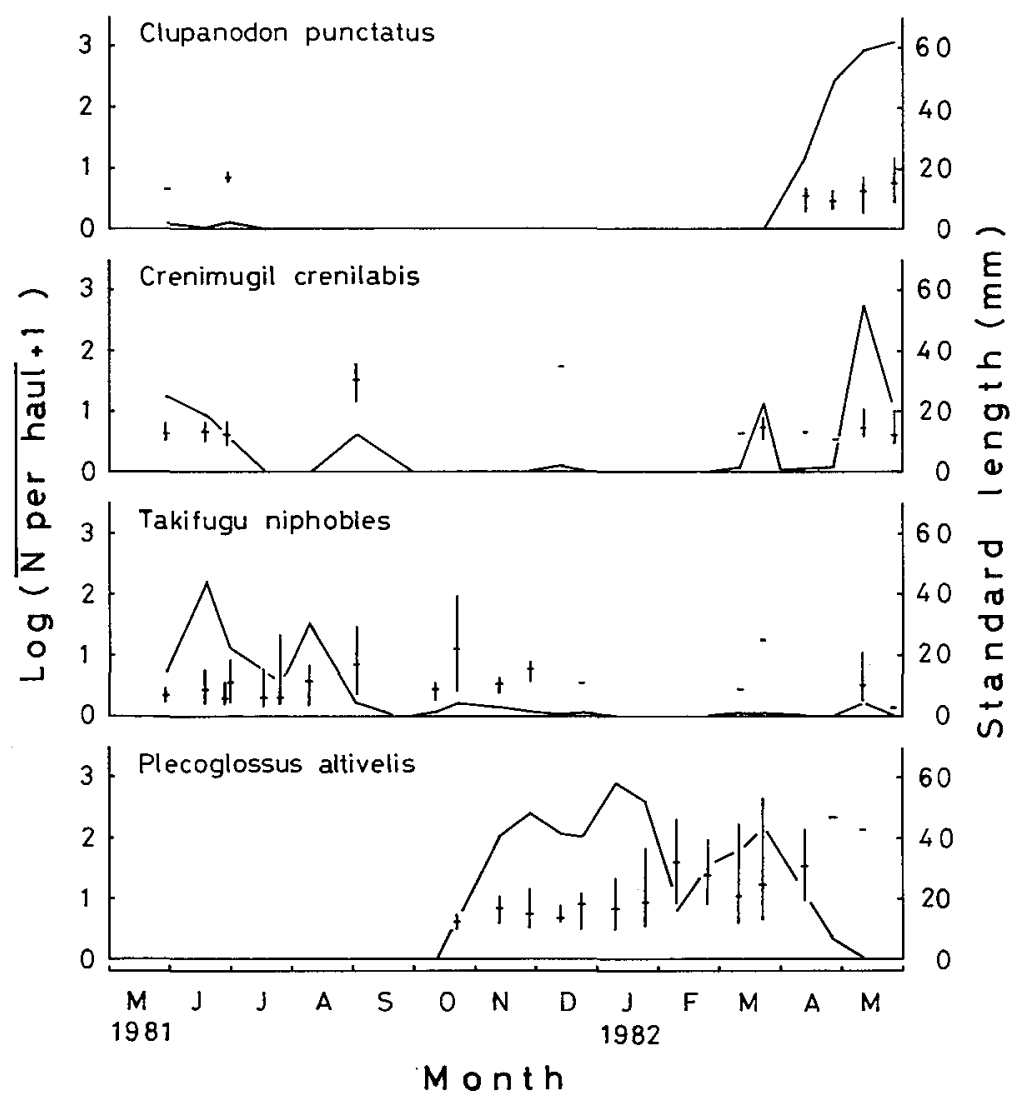

FIGURE 5.-Seasonal occurrence curves of the four most dominant species in the surf zones at three beaches on Tosa Bay. Horizontal and vertical bars in the figure indicate means and ranges of standard length, respectively.

89,296 fish of 91 species from 49 families. The species rankings differed somewhat from those of western Kyushu, but, again, the ichthyofauna of the surf zones showed marked differences from that of other nearby biotopes, especially coastal waters (Table 2).

\section{Size of Fish}

Even pelagic eggs of fishes occurred in the surf zones: 13,572 eggs of at least 16 species from the west coast of Kyushu and 1,169 eggs of more than 15 species from Tosa Bay. Regular members among them included Sardinops melanostictus, Clupanodon punctatus, Etrumeus teres, Anguilliformes sp., Saurida spp., Lateolabrax sp., Callionymidae spp., and Pleuronichthys cornutus.

Larvae and juveniles of most species collected in the surf zones never exceeded $15 \mathrm{~mm}$ SL (standard length) (Fig. 2). Milkfish, for example, occurred in our collections geographically from
Okinawa to Kii Peninsula and seasonally from early June to early November. Their sizes always fell in a narrow range from 9.3 to $14.4 \mathrm{~mm} \mathrm{SL}$ and length-frequency modes fell within 11.5-13.0 $\mathrm{mm}$.

A few species were represented by individuals as large as 50 to $60 \mathrm{~mm} \mathrm{SL}$, and showed length frequencies that varied with time and place (Fig. 3). This suggests that the narrow and small-sized length distributions shown in Fig. 2 are not necessarily attributable to gear selectivity. Our rearing experiments with milkfish collected in the surf zones showed that they transformed from larvae to juveniles in $10 \mathrm{~d}$ or so and began to take food on the bottom (Senta 1982). This change in feeding mode must necessitate a change in habitat from a sandy beach to a place rich with detrital materials such as an estuary or a mangrove area. Sparid fishes are known to shift from a pelagic life to a demersal at 14 to $15 \mathrm{~mm}$ TL (e.g., Tanaka 1980), and this may explain their 

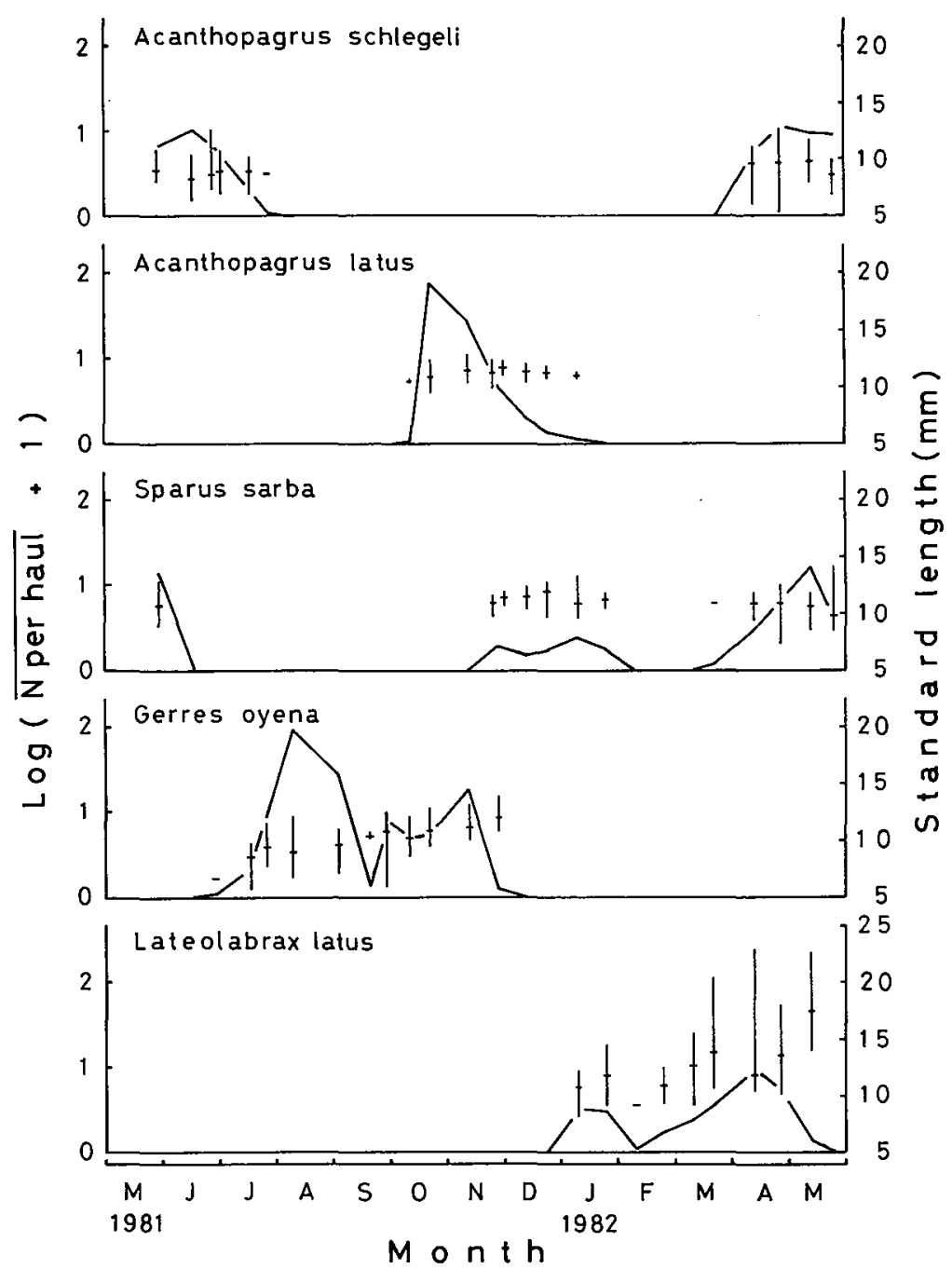

FIGURE 6.-Seasonal occurrence curves of five species characteristic of surf zones at three beaches on Tosa Bay. Horizontal and vertical bars indicate means and ranges of standard length, respectively.

disappearance from our collections after reaching 12 to $13 \mathrm{~mm} \mathrm{SL} \mathrm{(}=15.4$ to $16.6 \mathrm{~mm}$ TL). In case of Takifugu niphobles, however, the net avoidance by larger fish is the factor limiting the size of fish appearing in our collections. We often observed these fish up to $10 \mathrm{~cm}$ TL or so swimming in front of us while we were towing the seine.

\section{Seasonal Abundance}

In semimonthly collections at the three beaches on the Tosa Bay coast, more species were usually collected in spring and summer than in autumn and winter, although the number of species occurring in samples of any given month fluctuated between years (Fig. 4).

The strong monthly fluctuations in catch per haul (Fig. 4) were associated with changing abundances of individual species (Figs. 5 and 6). Abundances and the months of peak occurrence of all species varied considerably from year to year. Catches of a particular species often differed greatly between adjacent beaches on the same sampling day.

Many species, whether annual dominants (Fig. 5) or less abundant taxa that have seldom or never have been collected with traditional gears such as plankton nets (Fig. 6), showed no increase 


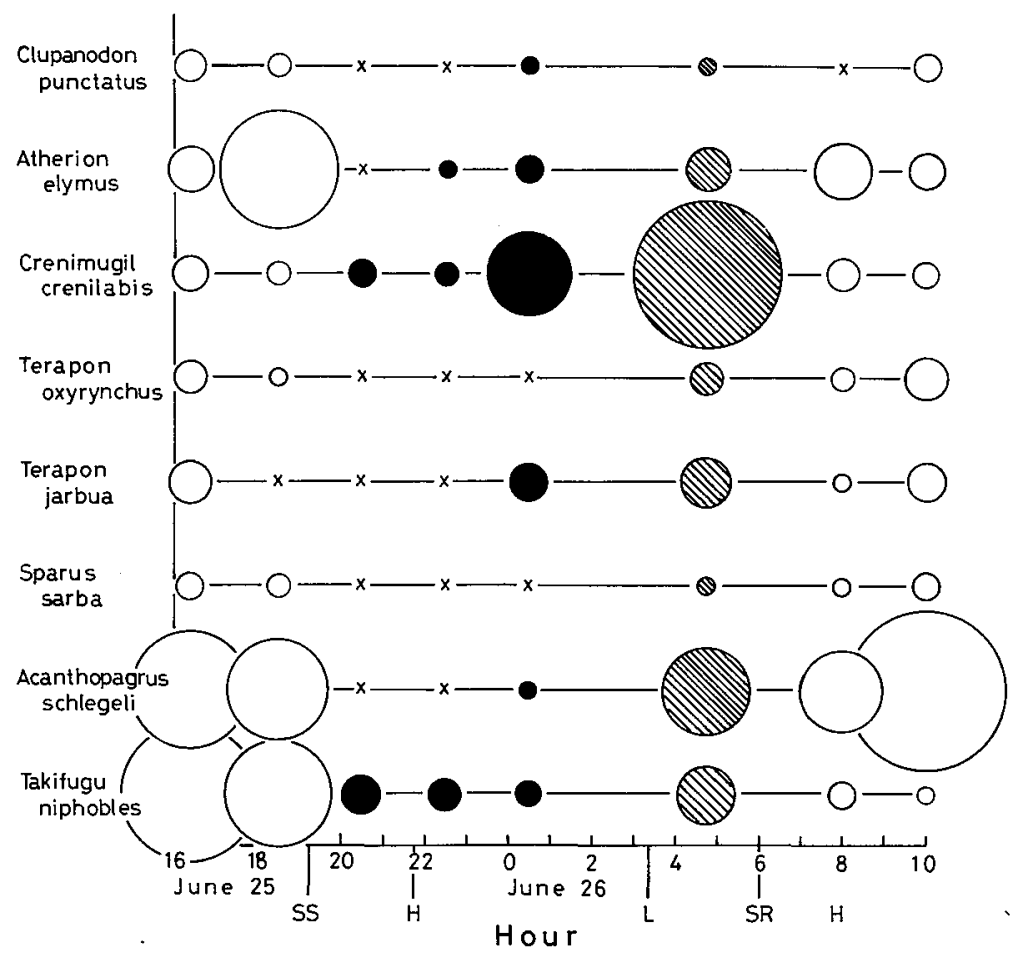

FIGURE 7.-A summary of day and night collections at Tanesaki on June 25-26, 1982. The diameter of each circle is drawn in proportion to the cube root of number of fish collected, of which the largest was 1,036 Acanthopagrus schlegeli at 1000 hours on June 26. Solid and shaded circles represent collections in darkness and in twilight, respectively. SS and SR represent sunset and sunrise; $H$ and $L$ represent high and low tide.

in mean length in samples covering several months. This indicates prolonged spawning periods for these species, and suggests that their larvae are "migrants" (Modde 1980) through the surf zone, although it is also possible that some of these fishes avoid the net or change to a demersal habit once they reach a certain size.

Of a special interest is Plecoglossus altivelis (Fig. 5) which is an amphidromous fish. Larvae first appeared in October and increased in abundance with no change in the mean standard length toward the middle of the following January, indicating a prolonged spawning in rivers and a successive dispersal of larvae to deeper water after they grow to a certain size along the shore. A short interposed period of low abundance in February indicates the cessation of larval recruitment from the rivers. With the rising temperature, the fish, now grown to juveniles, come back to the shore, resulting in an increase in abundance in the surf zones. The decrease in abundance and final disappearance in April and May show a migration of juveniles into the rivers.

\section{Diurnal Abundance}

We made day-and-night collections at Tanesaki beach on June 25-26, 1982 and October 3031,1982 . We caught 4,953 fish of 28 species in June collections and 5,602 fish of 20 species in October collections. Larvae and juveniles of most of the dominant species were more abundant during the day than at night (Figs. 7 and 8); the only conspicuous exception was Crenimugil crenilabis. Abundance during the day and paucity at night were strikingly contrasting in Acanthopagrus schlegeli, A. latus, and Gerres oyena.

No clear relationship was seen between the abundance of larval fishes in surf zones and tidal phases. Senta and Hirai (1981) also found no relation between tidal phases and abundance of young milkfish occurring in the surf zone of $\mathrm{Ku}$ mano beach, Tanegashima. Our collections were made in water of wading depth, and the sampling station at a given site moved landward or seaward according to the tidal phase. This could be the reason why abundance of fishes in surf zones was not affected by tidal phases. 


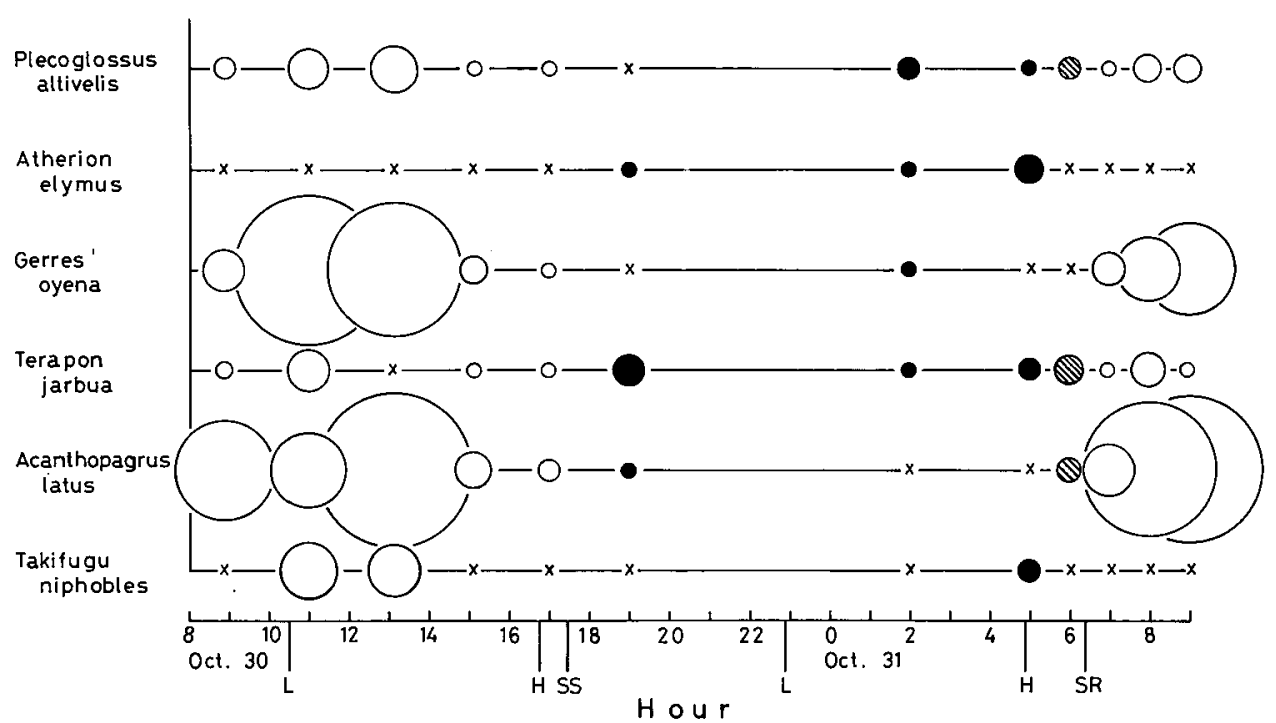

FIGURE 8. - A summary of day and night collections at Tanesaki on October 30-31, 1982. The largest circle, for Acanthopagrus latus at 1305 hours on October 30, represents 1,086 fish. Otherwise same as in Fig. 7.

\section{Demersal and Pelagic Components}

European sandy beaches are inhabited by larval flatfishes following metamorphosis, especially densely by Pleuronectes platessa (Macer 1967; Edwards and Steele 1968; Gibson 1973; Jones 1973; Lockwood 1974; Thijssen et al. 1974). Although larval flatfishes occurred in negligible numbers in our collections, scientists of the Seikai Regional Fisheries Research Laboratory in Nagasaki caught larval Paralichthys olivaceus with a small beam trawl in water from 50 $\mathrm{cm}$ to $3 \mathrm{~m}$ deep in a bay of Hirado island (Fig. 1) in months from April to July (M. Azeta, personal communication). The larval density was as high as six to eight fish per square meter in May.

All the nets used by scientists other than us who have worked on surf zone fishes, often on fish larvae, are designed to be towed along the sea bed. Their netting had stretched mesh sizes from $5 \mathrm{~mm}$ (Edwards 1973) to $37.5 \mathrm{~mm}$ (Schaefer 1967). On the other hand, the mesh width of plankton samplers, standard for offshore larval fish surveys, seldom exceeds $0.55 \mathrm{~mm}$ (Tranter and Smith 1968). The use of a fine mesh is precluded either for gear that is towed along the sea bed, because it scoops sediments, or for large nets, because of the increased drag resistance (McFarland 1963). Thus, a net with fine webbing can sample neither benthic fishes nor large mobile fishes effectively. The absence of larval flat- fishes and much smaller sizes of the specimens in our collections than those reported by other scientists are explained by the nature of our gear.

The surf zone fishes have been divided into categories according to feeding habits (Edwards 1973; Lasiak 1981, 1983), seasonal occurrence (Gunter 1958; McFarland 1963), and residence (Modde 1980). We consider that categorizing fishes of the surf zone into pelagic and demersal components is also useful. According to which of them we want to study, we should choose our gears.

The use of a gear for pelagic components also enables us to study larval and juvenile fishes inhabiting gravel and boulder beaches where the use of a gear moving along the sea bed is impossible.

\section{Acknowledgments}

Y. Tamamoto and H. Takemori helped us in the field surveys, and I. Takami and Y. Hidaka prepared illustrations. Shubun Fukudome, Chief of Nishinihon Technological Institute, encouraged us for the present study. We express our sincere thanks to them.

This work is supported partially by grants from the Ito Gyogaku Shinko Zaidan and the Nippon Life Insurance Foundation, and we express our gratitude for these. 


\section{References}

Edwards, R. R. C. 1973. Production ecology of two Caribbean marine ecosystems. I. Physical environment and fauna. Estuarine and Coastal Marine Science 1:303-318.

Edwards, R. R. C., and J. H. Steele. 1968. The ecology of 0-group plaice and common dabs in Loch Ewe. I. Population and food. Journal of Experimental Marine Biology and Ecology 2:215238.

Gibson, R. N. 1973. The intertidal movements and distribution of young fish on a sandy beach with special reference to the plaice (Pleuronectes platessa L.). Journal of Experimental Marine Biology and Ecology 12:79-102.

Gunter, G. 1958. Population studies of the shallow water fishes of an outer beach in south Texas. Publications of the Institute of Marine Sciences, University of Texas 5:186-193.

JONES, A. 1973. The ecology of young turbot, Scophthalmus maximus (L.), at Borth, Cardingshire, Wales. Journal of Fish Biology 5:367-383.

KIKUCHI, T. 1966. An ecological study on animal communities of the Zostera marina belt in Tomioka Bay, Amakusa, Kyushu. Publications from the Amakusa Marine Biological Laboratory, Kyushu University 1.

Kochisuishi. 1981. Survey on coastal fishery resources. Pages 46-59 in Annual Report S-54. Kochi Prefectural Fisheries Experimental Station, Kochi, Japan. (In Japanese.)

Kochisuishr. 1982. Exploitation surveys of fishery resources and fishing grounds. Pages 1-22 in Annual Report S-55. Kochi Prefectural Fisheries Experimental Station, Kochi, Japan. (In Japanese.)

KochisuishI. 1983. Survey on coastal fishery resources. Pages 1-13 in Annual Report S-56. Kochi Prefectural Fisheries Experiment Station, Kochi, Japan. (In Japanese.)

Kumagai, S., T. Bagarinao, and A. UngGui. 1980. A study on the milkfish fry fishing gears in Panay Island, Philippines. Southeast Asian Fisheries Development Center, Aquaculture Department Technical Report 6, Iloilo, Philippines.

LASIAK, T. A. 1981. Nursery grounds of juvenile teleosts: evidence from the surf zone of King's Beach, Port Elizabeth. South African Journal of Science 77:388-390.

LASIAK, T. A. 1983. The impact of surf-zone fish communities on faunal assemblages associated with sandy beaches. Pages 501-506 in A. McLachlan and T. Erasmus, editors. Sandy beaches as ecosystems. Dr. W. Junk, The Hague, The Netherlands.

Lockwoon, S. J. 1974. The settlement, distribution and movements of 0-group plaice Pleuronectes platessa (L.) in Filey Bay, Yorkshire. Journal of Fish Biology 6:465-477.

MACER, C. T. 1967. The food web in Red Wharf Bay (north Wales) with particular reference to young plaice (Pleuronectes platessa). Helgoländer Wissenschaftliche Meeresuntersuchungen 15:560-573.

Matsuda, S. 1969 . The studies on fish eggs and larvae occurred in the Nansei regional waters of Japan-I. Species occurred and their seasonal variation. Bulletin of the Nansei Regional Fisheries Research Laboratory 2:49-83.

MCFarLAND, W. N. 1963. Seasonal change in the number and the biomass of fishes from the surf at Mustang Island, Texas. Publications of the Institute of Marine Science, University of Texas 9:91105.

MCLACHLAN, A. 1983. Sandy beach ecology-a review. Pages 321-546 in A. McLachlan and $\mathrm{T}$. Erasmus, editors. Sandy beaches as ecosystems. Dr. W. Junk, The Hague, The Netherlands.

ModDE, T. 1980. Growth and residency of juvenile fishes within a surf zone habitat in the Gulf of Mexico. Gulf Research Reports 6:377-385.

SCHAEFER, R. H. 1967. Species composition, size and seasonal abundance of fish in the surf waters of Long Island. New York Fish and Game Journal 14:1-46.

SCHUSTER, W. H. 1952. Fish-culture in brackish-water ponds of Java. Indo-Pacific Fisheries Council Special Publications 1.

SENTA, T. 1956. Occurrence of a postlarval milkfish Chanos chanos (Forskål). Gotonada Narabini Sono Shuhen Chosa 23:54-56. Nagasaki Prefectural Fisheries Experimental Station, Nagasaki, Japan. (In Japanese.)

SENTA, T. 1964. Study on the distribution of eggs and larvae of fishes in the adjacent waters to western Japan. Bulletin of the Fisheries Experiment Station of Okayama Prefecture Special Number 1964, Okayama, Japan.

SentA, T. 1982. Milkfish in Japan - III. Seasonal occurrence of fry. Aquabiology 4:322-327. Tokyo, Japan.

Senta, T., AND A. Hirai. 1981. Seasonal occurrence of milkfish fry at Tanegashima and Yakushima in southern Japan. Japanese Journal of Ichthyology 28:45-51.

Senta, T., A. Hirai, K. Kanashiro, and H. Komaki. 1980. Geographical occurrence of milkfish, Chanos chanos (Forsskål) fry in southern Japan. Bulletin of the Faculty of Fisheries, Nagasaki University 48:19-26.

ShojIMA, Y., AND K. UekI. 1964. Studies on the larvae and juveniles of fishes accompanying floating algae-II. Research in vicinity of Tsuyazaki, during April, 1958-Mar., 1959. Bulletin of the Japanese Society of Scientific Fisheries 30:248-254.

TANAKA, M. 1980. The ecological studies on the larvae and juveniles of the red sea bream in Shijiki Bay-I. The horizontal distribution of the pelagic larvae and juveniles in and outside the bay. Bulletin of the Seikai Regional Fisheries Research Laboratory 54:231-258.

Thussen, R., A. J. LeVer, AND J. Lever. 1974. Food composition and feeding periodicity of 0 -group 
plaice (Pleuronectes platessa) in the tidal area of a sandy beach. Netherlands Journal of Sea Research 8:369-377.

Tranter, D. J., AND P. E. SMith. 1968. Filtration performance. UNESCO Monographs on Oceanographic Methodology 2:27-56.

UChIDA, K., AND Y. Dotsu. 1958. Fish eggs and larvae appearing in the surface layer of the warm Tsushima Current, a general review. Pages 3-65 in Tsushimadanryu Kaihatsu Chosa Hokokusho 2. Fisheries Agency, Tokyo, Japan. (In Japanese.) YosHIDA, H. 1932. On a post-larva of Chanos chanos (Forskål) from Amami-Oshima. Bulletin of the Japanese Society of Scientific Fisheries 1:25-27. YoshidA, H. 1933. On breeding and larvae of milkfish. Rakusuikaishi 28:25-30. Tokyo, Japan. (In Japanese.) 